\title{
A Sociolinguistic Analysis of Offensive Language in Astro Boy Movie
}

Engy Gaber El-Sayed Salama

Faculty of Arts, Benha University

engy.g.salama@gmail.com

\begin{abstract}
This paper tackles a sociolinguistic analysis of offensive words uttered by the characters in Astro Boy movie (2009) as one of the children's cinematic discourses. This research adopts Tagliamonte's (2012) social variables and Holms' (2013) social factors and social dimensions. This study aims to examine the social differences in using offensive language, the most recurrent types of offensive words in the selected movie and the functions and motives which lie behind these offensive words. The study proves the dominance of this form of language as a social norm in conversations and the mostly used types of offensive terms are those related to name-calling, verbal violence and insults that are preferred to express negative and aggressive emotions as well as to show intimacy, humor, solidarity and joy. These words are also used to discredit the counterparts and to provoke confrontations between distant participants.
\end{abstract}


Sociolinguistics, Social factors, Social Keywords:

variables, Social dimensions, Offensive words and Astro

Boy movie.

$$
\text { تحليل لغوى اجتماعى للغة المستهجنة في فيلم الفتى أسترو }
$$

تتناول هذه الدراسة تحليل لغوى اجتماعى للالفاظ المستهجنة المستخدمة في فيلم "الفتى أسترو" لعام 2009. واعتمد هذا البحث على دراسة المتغيرات والعوامل والابعاد الاجتماعية لتاجليمونت (2012) و هولمز (2013) لقياس مدى تأثير الفروق الاجتماعية على استخدام الالفاظ النابية في المجتمع الى جانب معرفة ما هي الأنواع الأكثر استخداماً في هذا الفيلم وأنواعها ووظيفتها اللغوية في الحوار. أوضحت الدراسة ان استخدام الالفاظ البذيئة أصبح متداولاً بشكل طبيعى في الحوار بغض النظر عن اختلاف الطبقة الاجتماعية والعمر والتعليم والنوع. أوضحت الدراسة أيضاً ان المتحدث يستخدم هذه الالفاظ للتعبير عن كلا من مشاعره السلبية والايجابية.

\section{Introduction}

Language is a significant medium of communication in any speech community for it can establish relationships among people (Wardhaugh\& Fuller, 2015). Through language, people can identify each other; it can reflect one's social background, character, identity and culture. Moreover, language is one of powerful means of expressing emotion either positive or negative. People have numerous ways in using language; some of them tend to use the bad 
type of language that is forbidden by all societies and all religions to express certain emotion and face most of life's problems.

Offensive language is one of the kids' movies negative effects. It has become a fertile ground for the circulation of such language, especially the animated movies that have great impact on children's memories, awareness in addition to the cognitive and behavioral development. Lippi-Green (2012) argues:

Children are shaped by the ideas that they are constantly presented in these films, especially when it comes to language stereotypes and ideologies. Children are not passive agents. They are very capable of assimilating bias and prejudices at very young ages. (p.6)

The current research is implemented to handle the offensive language that is exposed to young children in kids' movies. This form of language is acquired by hearing, formed by imitating and strengthened by practice. Therefore, this research looks closer at such serious social and linguistic phenomenon that threats the whole world and tries to find solutions to have conscious and normal generation.

\section{Statement of the research problem}

The major problem of this study lies in the researcher's observation of limited examination of offensive language usage in kid's movies which have not received the same 
scholarly attention as the adult movies. Thus, the aim of conducting this study is to enlarge the body of research on this subject and show that offensive language plays many significant functions in language.

\section{Rational \&Objectives of Study}

The objectives of this research are presented as follow:

- To delineate the different types of offensive words spoken in Astro Boy movie.

- To examine the functions of foul words that is mentioned in the selected movie.

- To understand the motives behind using offensive language in children's movie under analysis.

- To investigate the potential social consequences or impact of the offensive language on the audience/hearer.

- To test whether there are any differences in using rude language in the selected movie by social class, gender and age differences.

\section{Methodology}

The current research applies Tagliamonte's (2012) social variables and Holms' (2013) social factors and social dimensions model to achieve a comprehensive and meaningful analysis, both linguistically and socially, of the 
examination of offensive words that are widely used in media in general and children movies in specific.

\subsection{Tagliamonte's (2012) Social variables:}

The research applies Tagliamonte's (2012) Social variables model which consists of three main perspectives: social class, age and gender.

\section{- Social class:}

Social class is one of the essential factors that play a vital role in people's life. It influences the attitude, values and linguistic choices of individuals in all societies. Through The social stratification of English in New York City, William Labov (1966), an American linguist, was the pioneer to propose the concept of class in sociolinguistics. His approach is based on the relation between social class and language variation. He asserts that the way of speaking reflects the individual's social rank. Peter Trudgill (1974), Milroy and Milroy (1978) and Basil Bernstein (1975) are the best-known linguistic scholars who followed Labov's approach. The term "class" is defined by many sociologists. Each one understands and interprets this concept according to different perspectives which varied across time. In this research, the concept of "social class" is confined to its influence on language choices and the frequency of using bad words.

As stated by Wright (2003), "Classes are social categories sharing subjectively-salient attributes used by 
people to rank those categories within a system of economic stratification" (p. 1). These attributes are illustrated by Thelin (2019), he associates class with "tastes, the type of labor one performs, habits, education, the extent of control people have over their labor, language, and power" (p.2).

Crompton (2008) identifies social class through three different meaning. "First, class can be identified as a mark of prestige, certain lifestyle, status or culture. Second, it can be thought to indicate inequality in social and economic factors. In fact, the second meaning mainly refers to one's power or to the possessions one has". Through the third meaning, class can be realized as "actual or potential social and political factors". (p. 15-16)

Trudgill (1995, p.23), for his part, defines social class as a "term used to refer to any hierarchical ordering of groups within a society". Meanwhile, Milroy and Milroy (1992) argue that "Social class is fundamentally a concept designed to elucidate large-scale social, political, and economic structures and processes" (p.2). Wardhaugh (2006) adds that sociolinguists put some different scales in order to classify individuals in society within a certain social system. These scales are: "occupational and educational scale" (p. 148)

Class can be divided into three basic classes; upper, middle and lower (working). So, what are the major factors that determine to which class the speaker belongs? Marx, Weber and Durkheim, sociologists and class analysts, relate 
the class of each individual to different measurements. Marx, for instance, concentrates on material factors (Wright, 2005); Weber depends on prestige, education and social power (Breen 2005), while Durkheim focuses on the interdependencies and shared belief systems that result from a division of labor (Grusky 2005).

Social class can be identified through one's language. Through speech, one can make a social profile for the speaker. It can reveal the speaker's identity, social and cultural environment. It can give a clue about the speaker's level of education and economic status. There is a correlation between economic status, education level and social class. The good financial level let people to get a higher education and ranked them in a certain social class. Accordingly, the high-class speaker offers information and uses knowledge in interaction, while the low-class speaker depends on his/ her emotion in conversation due to the lake of education level.

\section{- Age:}

In this study, the attention will be paid to handling age differences, of both the speaker and the hearer, in the light of the frequency of using bad words throughout the interaction. Jay (1992) highlights that, "Age of speakers and age of their addressees, as well, have proved to be significant variables in the social context of swearing. Children begin learning and using swear words of varying degrees of offensiveness from the time they start using 
normal language, and admonitions of this behavior quickly follow" (p. 71). In addition, teenagers use offensive words to express their maturity. Therefore, both children and teenagers associate their level of maturity with their verbal expressions.

Accordingly, age is one of the social patterns that play a crucial role in linguistic variation. As investigated by Kertzer and Keith (1984, cited in Murphy, 2010, p.1), "the aging process cannot be separated from the social, cultural, and historical changes that surround it. Therefore, we must learn how different cohorts age and how society itself is changed by these differences". Each individual passes through different stages in life; childhood, adolescence, adulthood and old age. A person began to grow not only physically and psychologically but also linguistically. Due to this alteration, language differs from person to another according to age differences. The child, for instance, speaks in a very different way than the adult. Labov (1994) proclaims that, "generational change is the basic model for sound change" (p. 112).

Age grading, generational change and communal change are common terms in sociolinguistics accompanied with age variation. Andersen (2001) defines age grading as "linguistic characteristics of a particular age group that are temporary and are altered or abandoned as its members grow older" (p. 4). This means that, the individual's way of speaking changes by the alteration of his/her stage of life. 
Each stage of life has certain linguistic characteristics. Elder people, for instance, began to use non-standard form of language, unlike an adult person who tends to use the standard linguistic features.

\section{- Gender:}

Sex and gender are two synonyms' terms. Tagliamonte (2012) distinguishes between sex and gender as terms related to male/female differences. He states that sex, on one hand, "refers to the physiological distinction between males and female". Gender, on the other hand, "refers to the social and cultural roles that individuals appropriate depending on their opportunities, expectations, and life experiences" (p.64).

Johnson and Repta (2012), from their part, define Sex as "a biological construct that encapsulates the anatomical, physiological, genetic, and hormonal variation that exists in species" (p.19). Eckert and McConnell-Ginet (2003) also assert that "Gender consists in a pattern of relations that develops over time to define male and female, masculinity and femininity, simultaneously structuring and regulating people's relation to society. It is deeply embedded in every aspect of society- in our institutions, in public spaces, in art, clothing, and movement." (p.33)

From a sociolinguistic point of view, gender is one of the main social factors that influence the individual's linguistic choices. Tagliamonte (2012) outlines that "of all the sociolinguistic principles, the clearest and most 
consistent one is the contrast between women and men" ( $p$. 32). The relationship between language and gender became a major point of interest for researchers in sociolinguistics. $\mathrm{Gu}$ (2013) elaborates, "gender difference is not only a reflection of the speeches between male and female, but also a reflection of their different living styles and attitudes" ( $p$. 248). With regard to this, Men and women are completely different; they have different characteristics, values and social roles. Each individual of both genders has certain rights and duties in community. Thus, these differences influence their own language. The male's way of speaking is totally different from their female counterparts. Each one of them has his/her own style and word choices in expressing the inner feelings. Tannen (1992 as cited in Hashamdar, 2018, p. 624) explains the meaning of language to both genders. She points out, "For women, speech is a way of creating connection and solidarity; while for men; it is a way to preserve independence and maintain status in a hierarchical social order".

Many studies emphasize that men use vernacular and non-standard language, while women tend to use powerless and standard language. This is a controversial and debatable issue. On one hand, some researchers as Hughes (1992) argues that "women are expected to be more polite and correct in their speech due to their inferior status and because they carry the responsibility for transmitting the norms of speech to children" (p. 292). This means that, women try to avoid using bad words in their speech to keep 
the traditional stereotype of the female who must behave as a lady. They use "super polite forms, e.g., ambiguous requests, euphemisms and resistance of powerful swear words" (Lakoff, 2004, p. 78). Compared to females, Dooling (1996) denotes that "men swear because they are uncouth warthogs by nature, and they especially love to say bad words because it makes them feel manly in some violent, disturbing way, which (government studies will someday show) is indicative of the male need to exploit, debase, and discriminate against women" (p. 5).

\subsection{Holm's (2013) model}

\subsubsection{Social factors}

Holms (2013, p.8) asserts that one's choice of language is influenced by the following elements:

> The participants (speaker/ hearer): deals with the interlocutors involved in the interaction.

$>$ The setting or social context: concerns with the time and place in which the conversation takes place. When and where the participants are speaking? Such as home, school, bank and etc.... social context also determines the language choice.

The topic: is the key of any conversation. It concerns with what is being talked about? Through the topic, one can know speakers' emotions and their tone in speech. A person's emotion determines his/her tone in 
interaction such as anger, happiness, frustration, joking and etc.

$>$ The function: deals with the purpose of the conversation either social or informative. Why are the interlocutors speaking? Holmes (2013, p.275) classifies the function of speech into six categories: Expressive, Directive, Referential, Metalinguistic utterances, Poetic and Phatic utterances

\subsubsection{Social dimensions}

Holms (2013, p.9) sets four different scales that can affect language use:

$>$ A social distance scale focuses on the relationship between participants. This relationship can determine their linguistic choice and the degree of understanding each other. It refers to the degree of solidarity between the speaker and the hearer. Wardhaugh (2015) defines solidarity as "the motivations which cause individuals to act together and to feel a common bond which influences their social actions. Thus, the concept of solidarity is intertwined with both identity formation and group formation" (p.9). The term "solidarity" is used, in this scale, to measure the level of closeness and intimacy amongst the interlocutors. Conversation became more formal when the social distance 
increases whilst the informality increases when the social distance became little between speakers.

$>$ A status scale deals with the relationship between participants in terms of social status and position in society. According to Holms (2013), "Social status" and "power" are two fundamental factors in this scale that are parallel connected together. A person of high social position in society has the power in communication, is considered "superior" and placed in the high rank of the scale. On the contrary, a person of low social position is considered as "subordinate" and is located at the bottom of this scale. In other words, there are some material things such as wealth, family background, education, profession and so which control the degree of formality in conversation. People of high social status have the right to talk in both formal and in formal with the lower ones, but people of low social status must only talk in formal way with the high ones. The manager, for instance, is a high social status (superior) and must be respected by his employees (subordinate).

A formality scale concerns with the setting or type of interaction. The setting of conversation determines the language choice such as law court, church, school, private home and etc. (Holms, 2013) besides, the degree of Formality differs according to the situation or the circumstances by which the 
speakers can determine to be formal or in formal in communication. Wardhaugh (1992) clarifies that "People may also try to relate the level of formality chosen to a variety of factors: the kinds of occasions, various social backgrounds, and emotional involvement of one or more of the participants" (P. 48).

$>$ Two referential and affective function scales: concerns with the purposes or topic of interaction. According to Holms (2013) "Language can convey objective information of a referential kind; and it can also express how someone is feeling" (p. 10). The referential scale contains two types of information content: high and low. Similarly, the affective scale has two forms of affective content: high and low. But these two scales are completely "inversely proportional" (Georgieva, 2014, p. 4).

\section{Analysis}

The researcher presents two extracts from the movie as examples of its analysis:

\section{Extract one:}

"He's a dangerous $\underline{\text { idiot }}$ who happens to have a high IQ"

- Social variables (social class, age and gender) 
The word "idiot" is used by president Stone, an adult man who belongs to the upper class in general and upperupper class in specific. President Stone uttered this word to Dr. Tenma, whose black hair and Strong physique denote their being in $40 \mathrm{~s}$.

- Social factors (participants, setting, topic and function)

In the Ministry of Science Dr. Tenma's friend, Dr. Elephun discovers two opposite red and blue energy domains which have negative and positive effects. Dr. Elephun believes that blue core energy is very safe one that can purify the polluting surfaces, but President Stone supposes that red core energy is suitable for the peacekeeper. Stone uttered the expressive utterance "idiot", in this situation, for impressing with the vision of Dr. Elephun.

- Social dimensions (social distance, status, formality, referential and effective function scales)

This interaction occurs between two intimate participants: President Stone and Dr. Tenma. The first is a politician leader who wants to be re-elected and control Metro City through constructing the peacekeeper and the other who is a roboticist and head of the Ministry of Science. The choice of the word "idiot" refers to the high intimacy and the less formality between the two participants. The high position of Stone gives him the free choice to be informal with Dr. Tenma in expressing his 
feelings about what's demonstrated by Dr. Elephun. Thus, this word has an affective function for expressing certain feelings.

\section{Extract Two:}

"The only way you can, Doctor. I'm gonna kick some butt"

\section{- Social variables (social class, age and gender)}

The word "butt" is uttered by President Stone, an adult political man in his forties who is depicted as an upper-class person. He uses this abusive word in threating Dr. Elepun, an elder man who belongs to middle class. Dr. Elephun's white hair indicates that he is approximately in 50s.

- Social factors (participants, setting, topic and function)

This interaction occurs in the Ministry of science between President Stone and Dr. Elephun. During Dr. Elephun's presentation about the two-core energy, Stone orders his guards to take over those two-core energy. But, when Dr. Elephun opposes them, Stone threats that he will get rid of anybody expostulate his desire of being re-elected. Stone uses the word "butt", in this situation, as indirect directive utterance to impose dominance over Dr. Elephun.

- Social dimensions (social distance, status, formality, referential and effective function scales) 
The word "butt" is uttered in interaction that occurs between two distant participants: President Stone and Dr. Elephun. The former is a politician chief who wants to use science to destruct the world. He attempts to gain the people's support by waging a false cold war using the slogan there is no time for change. The latter is a smart scientist in the Ministry of Science who dreams to deploy peace and safety in the world through science. The choice of the word "butt" refers to the low solidarity and high formality between the involved interlocutors. The high status of Stone gives him the opportunity to be formal with his subordinate (Dr. Elephun) and to Force him to obey his orders. Stone's use of such word is referential, because he gives the hearer information about the penalty for violating his orders.

\section{Conclusion}

\subsection{The frequency of offensive utterances occurrence in Astro Boy movie}

In this movie, eight extracts of different situations have been analyzed. The following table provides a summary of the offensive words that are mentioned in these extracts with its categories, motives, functions and social variables. This table answers the major formulated research questions as follows: 


\begin{tabular}{|c|c|c|c|c|c|}
\hline \multicolumn{4}{|c|}{ الجزء الثالث } & \multicolumn{2}{|c|}{ كلية الآداب والعلوم الإنسانية } \\
\hline $\begin{array}{l}\text { Offensive } \\
\text { utterance } \\
\text { No. } \\
\text { occurrence }\end{array}$ & & Category & $\begin{array}{l}\text { Motive } \\
\text { (emotion) }\end{array}$ & Function & Social variables \\
\hline Idiot & 1 & Name-calling & $\begin{array}{l}\text { Habit } \\
\text { (impressed) }\end{array}$ & $\begin{array}{l}\text { To discredit } \\
\text { someone }\end{array}$ & $\begin{array}{l}\text { By Stone (an adult } \\
\text { Politian leader- upper } \\
\text { class- male) }\end{array}$ \\
\hline Butt & 2 & Vulgar & $\begin{array}{l}\text { Threat and } \\
\text { astonishment }\end{array}$ & $\begin{array}{l}\text { To discredit } \\
\text { someone and } \\
\text { To draw the } \\
\text { viewer's } \\
\text { attention }\end{array}$ & $\begin{array}{l}\text { Stone }(40-50 \text { s) } \\
\text { Astro (a child robot } \\
\text { from middle class- } 13 \\
\text { years old) }\end{array}$ \\
\hline Crazy & 3 & Name-calling & $\begin{array}{l}\text { sadness and } \\
\text { astonishment }\end{array}$ & $\begin{array}{l}\text { To provide } \\
\text { catharsis }\end{array}$ & $\begin{array}{l}\text { Dr. Elephun (an elder } \\
\text { scientist- male -50s) } \\
\text { One of dr. Tenma's } \\
\text { team (an adult man } \\
\text { from } 30-40 \text { s) } \\
\text { Mr. Squirt (an adult } \\
\text { robot- male-working } \\
\text { class) }\end{array}$ \\
\hline Dumb & 1 & Name-calling & $\begin{array}{l}\text { Insulting } \\
\text { (anger) }\end{array}$ & $\begin{array}{l}\text { To discredit } \\
\text { someone }\end{array}$ & An adult robot- male \\
\hline Dummy & 1 & $\begin{array}{l}\text { Weak swear } \\
\text { word }\end{array}$ & Endearment & $\begin{array}{l}\text { To establish } \\
\text { interpersonal } \\
\text { identification }\end{array}$ & $\begin{array}{l}\text { Mr. Squirt (an adult } \\
\text { robot- male - working } \\
\text { class) }\end{array}$ \\
\hline
\end{tabular}




\begin{tabular}{|l|l|l|l|l|l|}
\hline Dirty & 1 & $\begin{array}{l}\text { Verbal violent } \\
\text { trivializing) }\end{array}$ & $\begin{array}{l}\text { Insulting } \\
\text { (anger) }\end{array}$ & $\begin{array}{l}\text { To discredit } \\
\text { someone }\end{array}$ & $\begin{array}{l}\text { Stone (adult-male- } \\
\text { upper class- Politian) }\end{array}$ \\
\hline Ugly & 1 & Name-calling & Insulting & $\begin{array}{l}\text { To discredit } \\
\text { someone }\end{array}$ & $\begin{array}{l}\text { Sparx (adult- low } \\
\text { class-male) }\end{array}$ \\
\hline Stupid & 3 & Name-calling & $\begin{array}{l}\text { Anger and } \\
\text { sadness }\end{array}$ & $\begin{array}{l}\text { To provide } \\
\text { catharsis and } \\
\text { discredit } \\
\text { something } \\
\text { girl-low class-17 years } \\
\text { old) }\end{array}$ & $\begin{array}{l}\text { Dr. Tenma (an adult } \\
\text { scientist- middle class- } \\
\text { male -40s) } \\
\text { Zane (an orphan child- } \\
\text { male- uneducated- low } \\
\text { class }\end{array}$ \\
\hline
\end{tabular}

Table (1): List of offensive words included in Astro Boy movie.

Based on the table above, it is noticeable that the most frequent categories are name-calling by using the words crazy and stupid in a same percentage $(23 \%)$, and vulgarity by utilizing the word butt with an average of (16\%). It also shows that twelve words of the eight extracts are uttered by male characters and one word by a female one (Cora). The researcher notices that there is only one female character in this movie. So, it can be found that both genders use offensive words to express certain emotion and to discredit the addressee. The next figure shows the percentages of the offensive words included in Astro Boy movie as follow: 


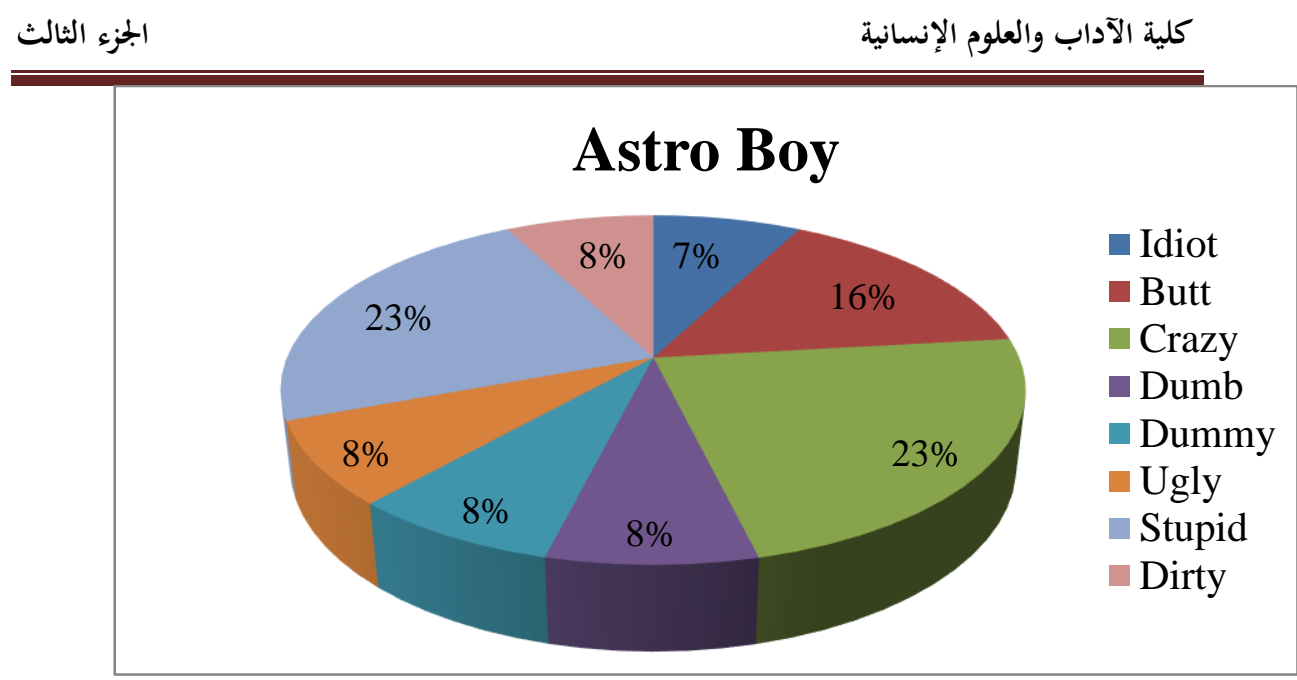

Figure (1): Frequencies of occurrence of the offensive words in Astro Boy movie 


\section{References}

Andersen, G. (2001). Pragmatic markers and sociolinguistic variation: A relevance theoretic approach to language of adolescents. Amsterdam: John Benjamins Publishing Campany.

Breen, R. (2005). Foundations of a Neo-Weberian class analysis. In E. O. Wright (Ed.), Approaches to class analysis (pp. 31-50). Cambridge: Cambridge University Press.

Crompton, R. (2008). Class and Stratifications ( ${ }^{\text {rd }}$ ed.). Cambridge: Polity Press.

Georgieva, M. (2014). Introducing sociolinguistics. University of Sofia. https://research.unisofia.bg/handle/10506/1209

Grusky, D. B. (2005). Foundations of a NeoDurkheimian class analysis. In E. O. Wright (Ed.), Approaches to class analysis (pp. 51-81). Cambridge: Cambridge University Press.

Holms, J. (2013). An introduction to sociolinguistics $\left(4^{\text {th }}\right.$ Ed). London\& NewYork: Routledge.

Jay, T. (1992). Cursing in America: A psycholinguistic study of dirty language in the courts, in the movies, in the schoolyards and on the streets. Philadelphia: John Benjamins. 
Labov, W. (1994). Principles of linguistic change: Internal factors. Oxford: Blackwell.

Lippi-Green, R. (2012). English with an accent: Language, ideology and discrimination in the United States $\left(2^{\text {nd }} \mathrm{ed}\right)$. London\& New York: Routledge.

Milroy, L., \& Milroy, J. (1992). Social Network and Social Class: Toward an Integrated Sociolinguistic Model. Language in Society, 21(1), 1-26. http://www.jstor.org/stable/4168309

Murphy, B. (2010). Corpus and sociolinguistics: Investigating age and gender in female talk. Amsterdam: John

Benjamins. https://books.google.com.eg/books?id=FKAveyWyW2sC\& printsec $=$ frontcover $\& d q=$ murphy,+ br\%C3\%B3na. $+2010 .+\mathrm{c}$ orpus+and+sociolinguistics.+investigating+age+and+gender $\underline{+ \text { in }+ \text { female }+ \text { talk }+ \text { pdf\&hl=en\&sa }=X \& v e d=0 a h U K E w j i 39 i 7}$ qLXkAhUNzhoKHescDIcQ6AEIKTAA\#v=onepage\&q\&f= $\underline{\text { false }}$

Tagliamonte, S. (2012). Variationist sociolinguistics: Change, observation, interpretation. Oxford: WileyBlackwell.

Trudgill, P. (1974). The Social Stratification of English in Norwich. London: Cambridge University Press.

-------------. (1995). Sociolinguistics: An Introduction to Language and Society. London: Penguin. 
Wardhaugh, R. (2006). An Introduction to Sociolinguistics $\left(5^{\text {th }}\right.$ Ed). Blackwell Publishing Ltd.

Wardhaugh, R., \& Fuller, M. J. (2015). An introduction to sociolinguistics $\left(7^{\text {th }}\right.$ Ed). Wiley Blackwell, Blackwell.

Wright, E. O. (2003). "Social Class". University of Wisconsin - Madison: Department of Sociology, pp. 1-16. https://www.ssc.wisc.edu/ wright/Social\%20Class\%20-\%20Sage.pdf 